\title{
Destilasi Bioetanol dari Nira Aren dengan Variasi Waktu Pengadukan pada Proses Fermentasi
}

\author{
Andika Latara $^{1)}$, Sjahril Botutihe ${ }^{2)}$, Mustofa $^{3)}$ \\ 1,2,3) Program Studi Mesin dan Peralatan Pertanian, Politeknik Gorontalo \\ Jl. Muchlis Rahim, Desa Ponggulo Barat, Kec. Botupingge, Kab. Bone Bolango, Gorontalo, Indonesia \\ e-mail: andikalatara343@gmail.com
}

\begin{abstract}
ABSTRAK
Bioetanol merupakan salah satu jenis energi terbarukan yang dapat dimanfaatkan sebagai bahan bakar kendaraan bermotor menggantikan bensin dan pertalite. Bioetanol umumnya diperoleh dari produk-produk pertanian, baik yang berupa padatan seperti dari ubi-ubian atau produk cair seperti nira nipah atau nira aren. Produksi bioetanol umumnya dilakukan dengan metode destilasi dengan memanfaatkan perbedaan titik didih antara zat yang akan dipisahkan, dalam hal ini etanol dan air. Sebelum proses destilasi, bahan sumber bioetanol dilakukan proses fermentasi dengan bantuan ragi. Tujuan penelitian adalah untuk mengetahui kadar alkohol dari bioetanol yang dihasilkan dengan perbedaan waktu pengadukan selama fermentasi. Produksi bioetanol pada penelitian ini dilakukan melalui serangkaian tahapan kegiatan meliputi pasteurisasi, fermentasi, dan destilasi. Proses fermentasi bioetanol berlangsung selama 3 hari setelah proses pasteurisasi. Selama fermentasi, air nira diaduk dengan dua variasi waktu pengadukan yang berbeda, yaitu 3 menit dan 6 menit setiap 6 jam sekali. Adapun alat dan bahan yang digunakan dalam penelitian ini adalah alat destilasi, kompor gas, $\mathrm{pH}$ meter, termometer, alkohol meter, pompa air, air pendingin, nira aren, ragi dan gas LPG. Berdasarkan hasil pengujian diketahui bahwa semakin lama waktu pengadukan saat fermentasi dapat meningkatkan kadar alkohol dari bioetanol yang dihasilkan. Proses pengadukan selama 3 menit menghasilkan bioetanol dengan kadar alkohol 49\%, sedangkan peningkatan waktu pengadukan menjadi 6 menit berkontribusi pada peningkatan kadar alkohol menjadi 55\%. Dengan demikian, dapat disimpulkan bahwa waktu pengadukan saat fermentasi bioetanol memiliki peran dalam peningkatan kualitas etanol yang dihasilkan.
\end{abstract}

Kata Kunci: bioetanol, nira aren, pasteurisasi, fermentasi, destilasi

\begin{abstract}
Bioethanol is one type of renewable energy that can be used as a fuel to replace gasoline and pertalite. Bioethanol is generally produced from agricultural products, either in the form of solids such as from sweet potatoes or liquid products such as nipa sap or palm sap. Bioethanol production is generally carried out by the distillation method by utilizing the difference in boiling points between the substances to be separated, in this case ethanol and water. Before the distillation process, the bioethanol source material is fermented with the addition of yeast. The purpose of this study was to determine the alcohol content of the bioethanol produced by the difference in stirring time during fermentation. The production of bioethanol in this study was carried out through a series of activities including pasteurization, fermentation, and distillation. The bioethanol fermentation process lasts for 3 days after the pasteurization process. During fermentation, palm sap is stirred with two different variations of stirring time, namely 3 minutes and 6 minutes every 6 hours. The tools and materials used in this research are distillation apparatus, gas stove, $p H$ meter, thermometer, alcohol meter, water pump, cooling water, palm sap, yeast and LPG gas. Based on the test results, it is known that the longer stirring time during fermentation can increase the alcohol content of the bioethanol produced. The stirring process for 3 minutes produced bioethanol with an alcohol content of 49\%, while increasing the stirring time to 6 minutes contributed to an increase in the alcohol content to 55\%. Thus, it can be concluded that the stirring time during bioethanol fermentation has a role in improving the quality of the ethanol produced.
\end{abstract}

Keywords: bioethanol, palm sap, pasteurization, fermentation, destilation 


\section{PENDAHULUAN}

Konsumsi bahan bakar minyak (BBM) telah diprediksi mengalami kenaikan dengan penyediaan yang semakin menurun untuk memenuhi konsumsi BBM tersebut, terutama untuk tahun 2017-2025 (Sa'adah, dkk., 2017). Di tahun 2019, peningkatan konsumsi BBM bergerak secara dinamis. Badan Pelaksana Kegiatan Hulu Minyak dan Gas Bumi (BPH Migas) mencatat konsumsi BBM selama masa posko nasional ESDM dalam menghadapi hari raya Idul Fitri 21 Mei hingga 17 Juni 2019 mencapai 2,87 juta kiloliter $(\mathrm{kL})$. Dengan rerata harian sebesar 02,56 ribu $\mathrm{kL}$ per hari, rata-rata konsumsi harian BBM tercatat naik 9,29\% dibanding rerata penyaluran normal dan meningkat 2,5\% dibandingkan penyaluran periode yang sama tahun 2018 (Arvirianty, 2019). Hal ini tentunya akan berpengaruh pada kelangkaan BBM sebagaimana prediksi di atas.

Untuk menanggulangi adanya konsumsi BBM berlebihan perlu adanya kebijakan yang mengatur kesediaan BBM dengan tingkat konsumsi masyarakat. Upaya tersebut telah dilakukan, khususnya pemerintah Provinsi Gorontalo dengan membentuk satgas gabungan untuk menerbitkan pengecer bahan bakar minyak (BBM). Hal ini dilakukan dengan beberapa alasan diantaranya para pengecer BBM dianggap membuat panjang antrean SPBU, khususnya untuk jenis premium dan juga berdampak pada stok BBM yang cepat berkurang. Hal ini menunjukkan bahwa masyarakat Gorontalo sangat tinggi konsumsi bahan bakar minyak, terutama jenis premium. Hal ini akan berdampak pada peningkatan suhu bumi akibat pencemaran lingkungan yang ditimbulkan dari emisi sisa pembakaran BBM tersebut. Diantara kandungan emisi yang sangat berbahaya adalah adanya kandungan $\mathrm{CO} / \mathrm{CO}_{2}$.

Penggunaan bahan bakar ini merupakan salah satu faktor utama penyumbang polusi udara. Gas buang yang dihasilkan dari proses pembakaran selain $\mathrm{CO}$ dan $\mathrm{CO}_{2}$ adalah nitrogen oksida, oksida belerang dan beberapa senyawa hidrokarbon. Selain itu, gas buang kendaraan juga mengandung partikulat-partikulat beracun yang paling mempengaruhi kesehatan manusia. Partikulatpartikulat ini merupakan campuran material padat dan cair yang terbentuk akibat pembakaran bahan bakar (Harismi, 2020).

Oleh karena itu perlu adanya bahan alternatif pengganti BBM, salah satunya bioetanol. Bioetanol merupakan salah satu energi terbarukan yang cocok digunakan untuk mengganti bahan bakar minyak. Penggunaan bioetanol sebagai BBM memiliki keunggulan memiliki daya bakar yang lebih baik. Hal ini karena proses pembakaran berlangsung secara sempurna sehingga mengurangi emisi gas karbon monoksida (Edward \& Riadi, 2015). Bioetanol dapat dibuat dari bahan padat dan bahan cair. Bahan baku padat dapat berupa singkong, gandum, tebu, sagu, ubi jalar, dan batang pisang. Sedangkan bahan baku cair berasal dari air nira nipah, nira sorgum manis, nira kelapa, nira aren, dan nira siwalan (Komaryati, dkk., 2014).

Dalam penelitian ini bahan baku yang digunakan sebagai sumber bioetanol adalah air nira aren. Pemilihan ini didasarkan pada beberapa tinjauan, yaitu potensi dan manfaat. Dari segi potensi, nira aren di Gorontalo masih tergolong cukup banyak banyak, terutama di wilayah Dulamayo Selatan (Gorontalo) yang sangat mudah dijumpai. Dari segi manfaat, masyarakat umumnya memanfaatkan tanaman aren untuk beberapa keperluan seperti pembuatan gula merah dari air nira, pembuatan sapu ijuk dan tali, serta pembuatan sapu lidi.

Bioetanol dibuat melalui serangkaian proses kimia berupa reaksi hidrolisis (persamaan reaksi 1) dan penguraian menjadi etanol (persamaan reaksi 2). Proses hidrolisis dimaksudkan untuk memecah polisakarida (gula kompleks) menjadi gula sederhana (glukosa, $\mathrm{C}_{6} \mathrm{H}_{12} \mathrm{O}_{6}$ ) dengan bantuan air. Sedangkan glukosa hasil hidrolisis diubah menjadi etanol $\left(\mathrm{C}_{2} \mathrm{H}_{5} \mathrm{OH}\right)$ dengan bantuan ragi pada proses fermentasi. Proses ini selain meghasilkan produk utama etanol juga menghasilkan gas karbon monoksida $\left(\mathrm{CO}_{2}\right)$.

$\left(\mathrm{C}_{6} \mathrm{H}_{10} \mathrm{O}_{5}\right)_{\mathrm{n}}+\mathrm{n} \mathrm{H}_{2} \mathrm{O} \rightarrow \mathrm{n} \mathrm{C}_{6} \mathrm{H}_{12} \mathrm{O}_{6}$

$\mathrm{C}_{6} \mathrm{H}_{12} \mathrm{O}_{6} \rightarrow \mathrm{C}_{2} \mathrm{H}_{5} \mathrm{OH}+2 \mathrm{CO}_{2}$

Proses fermentasi merupakan penguraian metabolik senyawa organik oleh mikroorganisme yang menghasilkan energi. Proses ini umumnya berlangsung dengan kondisi anaerobik dan dengan pembebasan gas. Untuk menghasilkan bioethanol dengan kadar alkohol yang lebih tinggi maka dilakukan proses lanjutan berupa pemurnian. Pemurnian bioetanol dilakukan dengan proses destilasi atau proses memanaskan benda cair atau padat hingga berubah menjadi uap yang disalurkan pada bejana yang terpisah, kemudian dikondensasikan dengan pendingin. Banyak aspek yang dapat mempengaruhi proses pembuatan bioetanol, salah satunya adalah proses pengadukan. 
Proses ini berfungsi untuk menghomogeniskan larutan dan memperluas permukaan kontak antara zat terlarut dan larutan sehingga proses semakin cepat berlangsung dan produk yang dihasilkan akan semakin banyak. Dengan memanfaatkan variasi waktu pengadukan diharapkan dapat memberikan konstribusi pada hasil bioetanol, terutama kualitasnya dari segi kadar alkohol.

\section{METODE PENELITIAN}

\section{Alat dan Bahan}

Alat dan bahan yang digunakan pada penelitian ini antara lain satu set alat destilasi, kompor gas, pompa air, $\mathrm{pH}$ meter, termometer, alkohol meter, nira aren, air pendingin, ragi, gas LPG.

\section{Prosedur Penelitian}

Prosedur penelitian dapat dilihat pada Gambar 1. Secara detail proses pembuatan bioetanol dilakukan menggunakan alat destilasi (Gambar 2) melalui tahapan-tahapan berikut.

1. Preparasi sampel

Preparasi sampel dilakukan dengan mengkarakterissai awal sampel nira aren. Karakterisasi dilakukan untuk pengecekkan $\mathrm{pH}$ awal sampel nira aren.

2. Pasteurisasi

Pasteurisasi dilakukan pada suhu $50-60 \quad{ }^{\circ} \mathrm{C}$ selama 10 menit.

3. Fermentasi

Proses fermentasi dilakukan pada suhu ruang selama 3 hari dengan penambahan ragi sebanyak 10 gr/liter. Pada proses fermentasi dilakukan pengadukan selam 6 jam sekali dengan variasi lamanya pengadukan selama 3 dan 6 menit.

4. Destilasi

Destilasi nira aren dilakukan setelah proses fermentasi selama 72 jam. Destilasi ini dilakukan pada suhu $78-80{ }^{\circ} \mathrm{C}$.

5. Uji kadar alkohol

Destilat yang diperoleh dari hasil destilasi dilakukan pengujian menggunakan alkohol meter untuk mengetahui kadar alkoholnya.

\section{Alat Destilasi}

Alat ini (Gambar 2) memiliki satu buah tabung dengan kapasitas maksimal 5 liter yang dilengkapi dengan dudukan kompor gas sebagai sumber

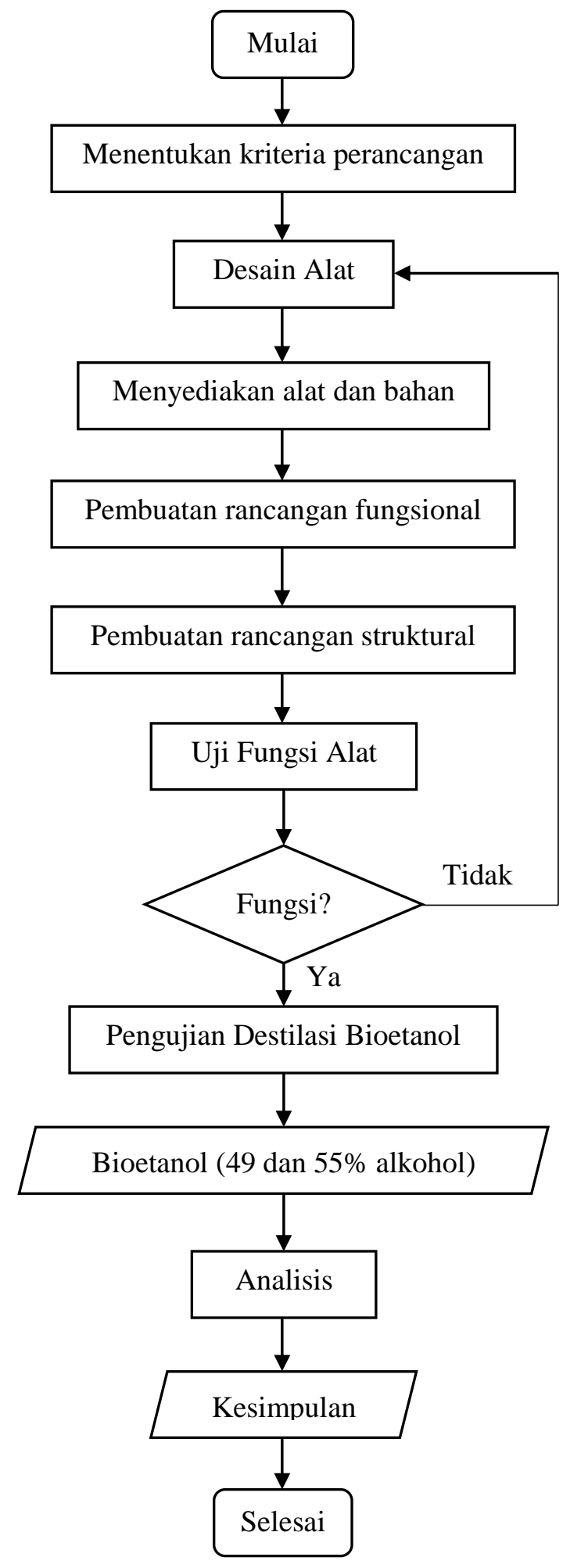

Gambar 1. Diagram Alir Penelitian

pemanasan dan dua buah kondensor. Tabung pada alat destilasi ini dapat dimanfaatkan sebagai tempat (wadah) pada proses pasteurisasi, fermentasi, dan destilasi. Sementara kondensor dimaksudkan untuk 
proses pendinginan (kondensasi) uap hasil pembakaran pada tabung sehingga menghasilkan etanol. Untuk membantu proses kondensasi, pada bagian kondensor dilengkapi dengan aliran air dingin sehingga proses kondensasi dapat berlangsung secara maksimal.

\section{HASIL DAN PEMBAHASAN}

Hasil penelitian pembuatan bioetanol dari nira aren dapat dilihat pada Tabel 1. Berdasarkan Tabel 1 diketahui bahwa peningkatan waktu pengadukan selama proses fermentasi dapat meningkatkan kadar alkohol bietanol.

Tabel 1. Hasil Pengujian Alat Destilasi Bioetanol

\begin{tabular}{l|c|c|c|c|c}
\hline \multicolumn{2}{c|}{ Sampel Awal } & \multirow{2}{|c}{ Bioetanol } \\
$\mathrm{V}(\mathrm{mL})$ & $\mathrm{pH}$ & $\begin{array}{c}\mathrm{t}^{*} \\
(\text { menit})\end{array}$ & $\begin{array}{c}\text { Kadar } \\
\text { Alkohol } \\
(\%)\end{array}$ & $\mathrm{pH})$ & $\begin{array}{c}\mathrm{V} \\
(\mathrm{mL})\end{array}$ \\
\hline 5000 & 2,63 & 3 & 49 & 4,65 & 500 \\
5000 & 2,63 & 6 & 55 & 4,59 & 200 \\
\hline
\end{tabular}

$t^{*}:$ waktu pengadukan saat fermentasi

\section{Preparasi Sampel}

Preparasi sampel dimaksudkan untuk mengetahui karakteristik awal nira aren. Nira aren diperoleh dari hasil penyadahan bunga aren oleh masyarakat. Hasil pengujian $\mathrm{pH}$ meter, nira aren memiliki $\mathrm{pH} 2,63$. Nilai ini menunjukkan bahwa nira aren tersebut memiliki tingkat keasaman yang tinggi. Nira aren memiliki kadar gula yang sangat bervariasi dan umumnya tidak lebih dari $20 \%$ dengan kandungan air yang sangat tinggi. Diantara yang mempengaruhinya adalah lokasi dimana pohon aren itu tumbuh. Kadar gula nira aren di daerah Tomohon berkisar antara 10-13\% (Pontoh, dkk., 2011). Di beberapa tempat lain, nira aren memiliki kadar gula dalam bentuk sukrosanya berkisar antara 12,3-17,4\% (Natawijaya, dkk., 2018). Sementara itu hasil uji nira aren yang berasal dari Telaga Biru (Gorontalo) diketahui bahwa kadar karbohidrat nira aren sebesar 8,21\% (Ismail, dkk., 2020).

\section{Proses Pasteurisasi}

Pasteurisasai dilakukan dengan proses pemanasan nira aren yang dimasukkan dalam tabung pada suhu $50-60{ }^{\circ} \mathrm{C}$ selama 10 menit. Pasteurisasi dilakukan bertujuan untuk membunuh organismeorganisme yang merugikan dan tidak digunakan

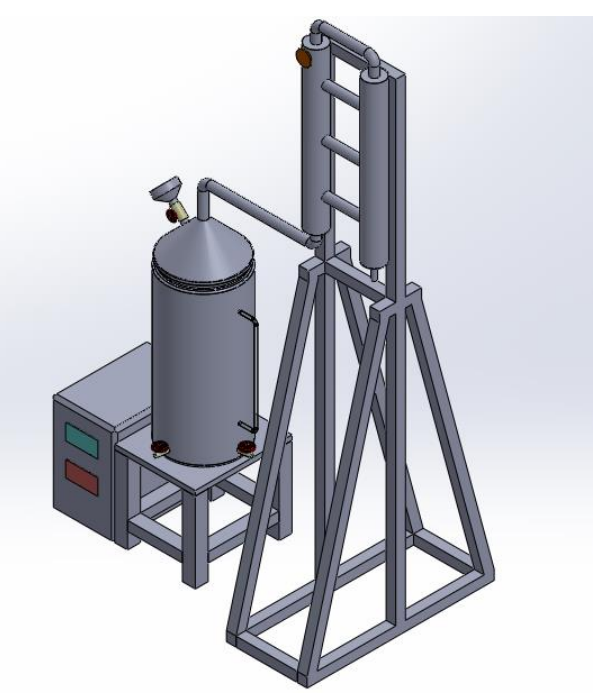

Gambar 2. Alat Destilasi Bioetanol

untuk proses selanjutrnya seperti bakteri, protozoa, dan lain-lain (Susmiati, 2011; Hendra, dkk., 2016).

\section{Fermentasi Nira Aren}

Pada penelitian ini, fermentasi nira aren dilakukan selama 3 hari (72 jam) dengan dilakukan proses pengadukan selama 6 jam sekali. Fermentasi bioetanol dilakukan pada suhu ruang dengan bantuan ragi sebanyak $10 \mathrm{gr} /$ liter. Fermentasi adalah proses pengubahan karbohidrat pada sampel menjadi alkohol dengan bantuan mikroorganisme (Saccharomyces cerevisiae) yang berasal dari ragi. Pemilihan mikroorganisme ini diketahui mampu menghasilkan alkohol dalam jumlah yang cukup tinggi dan memiliki ketahan hidup yang tinggi (Jefrries \& Jin, 2000). Pengadukan (agitasi) merupakan salah satu faktor yang dapat mempengaruhi biotenaol yang dihasilkan. Proses fermentasi yang dipadukan dengan proses agitasi dan aerasi mampu meningkatkan produksi etanol (Yan, dkk., 2009). Pada penelitian ini hanya dilakukan proses pengadukan selama fermentasi tanpa aerasi. Proses aerasi dan agitasi ini dapat membantu terjadinya peningkatan konsentrasi yeast dan konsumsi gula reduksi, sehingga meningkatkan produksi etanol (Jayus, dkk., 2016). Pengadukan dilakukan selama 6 jam sekali dengan variasi lamanya pengadukan 3 menit dan 6 menit. Fermentasi dilakukan selama 72 jam pada kondisi aerob ini mampu memproduksi etanol lebih cepat dibandingkan pada kondisi anaerob meskipun waktunya fermentasi ditambah (Xiros \& Christakopoulos, 2009). 


\section{Destilasi Bioetanol}

Destilasi bioetanol dilakukan setelah nira aren mengalami proses fermentasi selama 72 jam. Destilasi dilakukan dengan didasarkan pada perbedaan titik didih dari dua zat yang akan dipisahkan, yakni etanol dan air, dimana air memiliki titik didih $100{ }^{\circ} \mathrm{C}$ sedangankan etanol memiliki titik didih sekitar $78{ }^{\circ} \mathrm{C}$. Oleh karena itu, proses destilasi bioetanol dari nira aren dilakukan pada suhu antara $78-80{ }^{\circ} \mathrm{C}$. Hal ini karena pada rentang suhu tersebut terjadi pengubahan zat (khususnya etnaol) dari cairan ke gas. Gas hasil penguapan ini selanjutnya masuk ke saluran (selang) menuju kondensor sehingga terjadi kondensasi (pengubahan gas menjadi cair).

Berdasarkan hasil pengujian diperoleh bahhwa variasi pengadukan selama proses fermentasi mampu meningkatkan kadar alkohol bioetanol (Tabel 1). Kadar alkohol bioetanol dari hasil pengadukan 3 menit selama fermentasi adalah $49 \%$, sedangkan pengadukan selama 6 menit mampu menghasilkan bioetnaol dengan kadar alkohol 55\%. Pengujian kadar alkohol dilakukan menggunakan alat alkohol meter. Kadar ini tentunya masih dapat ditingkatkan, apalagi jika biotenaol digunakan sebagai bahan bakar harus memiliki kadar alkohol sebesar $99 \%$.

Faktor lain yang dapat meningkatkan kadar alkohol adalah dengan bantuan dehidrator pada proses dehidrasi bioetanol hasil destilasi (Hendra, dkk., 2015). Dehidrasi dilakukan dengan bantuan zeolit yang berfungsi untuk menyerap air pada campuran etanol sehingga dihasilkan etanol dengan kemurnian yang sangat tinggi. Peningkatan kemurnian bioetanol diikuti dengan penurunan volume biotenaol yang dihasilkan sebagai akibat dari air yang terserap oleh zeolit pada dehidrator.

\section{KESIMPULAN}

Berdasarkan hasil penelitian disimpulkan bahwa lamanya pengadukan saat fermentasi dapat meningkatkan kemurnian bioetanol. Pengadukan selama 3 menit menghasilkan bioetanol dengan kadar alkohol 49\%, sementara pengadukan selama 6 menit dapat meningkatkan bioetanol dengan kemurnian $55 \%$. Kadar ini tentunya masih perlu ditingkatkan lagi jika bioetanol digunakan sebagai bahan bakar.

\section{DAFTAR PUSTAKA}

Arvirianty, A., (2019), Konsumsi Bahan Bakar Melonjak 9,29\% Selama Idul Fitri, https://www.cnbcindonesia.com/news/2019061 9184957-4-79425/konsumsi-bensin-melonjak929-selama-idulfitri diakses pada tanggal 23 Oktober 2020.

Harismi, A., (2020), Dampak Pembakaran Bahan Bakar Kendaraan yang harus Anda Waspadai, https://www.sehatq.com/artikel/dampakpembakaran-bahan-bakar-bisa-berujung-padakematian diakses pada tanggal 23 Oktober 2020.

Hendra, D., Komaryati, S., \& Wibisono, H.S., (2016), Pembuatan Bioetanol dari Nira Nipah dengan Alat Hasil Rekayasa Tipe P3HH-1, Jurnal Penelitian Hasil Hutan, Vol. 34, No. 1, hal. 1-10.

Ismail, Y.N.N., Solang, M., \& Uno, W.D., (2020), Komposisi Proksimat dan Indeks Glikemik Nira Aren, Biospecies, Vol. 13, No. 2, hal. 1-9.

Jayus, J., Noorvita, I.V., \& Nurhayati., (2016), Produksi Bioetanol oleh Saccharomyces cerevisiae FNC 3210 pada Media Molases dengan Kecepatan Agitasi dan Aerasi yang Berbeda, Jurnal Agroteknologi, Vol. 10, No. 02, hal. 184-192.

Jeffries, T.W., \& Jin, Y.S., (2000), Ethanol and Thermotolerance in the Bioconversion of Xylose by Yeasts, Adv. Appl. Microbiology, 47, hal. 221-268.

Natawijaya, D., Suhartono, \& Undang, (2018), Analisis Rendemen Nira dan Kualitas Gula Aren (Arenga pinnata Merr.) di Kabupaten Tasikmalaya, Jurnal Agroforesti Indonesia, Vol. 1, No. 1, hal. 57-64.

Pontoh, J., Gunawan, I., \& Fatimah, F., (2011), Analisa Kandungan Protein dalam Nira Aren, Chem. Prog., Vol. 4, No. 2, hal. 75-79.

Sa'adah, A.F., Fauzi, A., \& Juanda, B., (2017), Peramalan Penyediaan dan Konsumsi Bahan Bakar Minyak Indonesia dengan Model Sistem Dinamik, Jurnal Ekonomi dan Pembangunan Indonesia, Vol. 17, No. 2, hal. 118-137.

Susmiati, Y., (2011), Detoksifikasi Hidrolisat Asam dari Ubi Kayu untuk Produksi Bioetanol, AGROINTEK, vol. 5, No. 1, hal. 9-15.

Xiros, C., \& Christakopoulos, P., (2009), Enhanced Ethanol Production from Brewer's Spent Grain by a Fusarium oxysporum Consolidated System, Biotechnology for Biofules, 2 (4), hal. 1-12. 
Yan, L., Tiansheng, Q., Naikun, S., Mingzhe, G., Yanling, G., \& Hai, Z., (2009), Improvement of Ethanol Concentration and Yield by Initial Aeration and Agitation Culture in Very Highy Gravity Fermentation, Cin. J. Appl. Environ. Biol., Vol. 15, No. 4, hal. 563-567. 